Michel Houellebecq, Sumisión (Barcelona: Anagrama, 2015).

RESEÑA

\title{
HOUELLEBECQ CONTRA EL MUNDO
}

\author{
Felipe Figueroa \\ Universidad de Warwick \\ Doris: "You have no values. With you it's all nihilism, \\ cynicism, sarcasm, and orgasm". \\ Harry Block: "Hey, in France I could run for office \\ with that slogan, and win!"' \\ Woody Allen, Deconstructing Harry (1997)
}

M ichel Houellebecq (o Thomas, su apellido de nacimiento) a simple vista parece un provocador. En efecto, es difícil toparse con un análisis de su obra que no sea al mismo tiempo un análisis de los aspectos públicos y privados de su vida. Marxista, conservador, narcisista, cínico, ateo, misógino, islamófobo. Son pocas las chapas que no le han colgado a este escritor con vocación de personaje (enfant terrible es la expresión siútica que se suele utilizar en estos casos). Algo de razón hay en todo esto. A menudo sus protagonistas tienen un sabor autobiográfico, lo que ha hecho al público y a los comentaristas tomar sin más las opiniones de sus personajes como propias. Sin embargo, esta tendencia a interpretar sus novelas como una defensa de los estilos de vida de sus personajes suele entorpecer el análisis de su obra. Así, la crítica suele terminar en alguna forma de evaluación moral del escritor. Esto

Felipe Figueroa. Abogado de la Universidad Adolfo Ibáñez. Magíster en derecho y nuevas tecnologías por la Universidad de Chile. Estudiante de doctorado en sociología, Universidad de Warwick. Email: felipe.figueroaz@gmail.com. 
es particularmente cierto en el caso de Sumisión ${ }^{1}$, su última novela. Narrada en primera persona desde la perspectiva de François, profesor de la Université Paris III-Sorbonne y experto en el escritor decadente Joris-Karl Huysmans, la novela se desarrolla en Francia en el año 2022 y relata el ascenso a la presidencia por parte de un grupo islamista moderado, dejando atrás la política bipartidista que hasta hoy ha caracterizado la política electoral francesa. La novela transcurre en dos fases. La primera parte corresponde a la época previa a las elecciones, caracterizada por el surgimiento de distintos actos de violencia extremista e incertidumbre. Luego, en la segunda fase (que toma la mayor parte de la novela), vemos al gobierno islámico, que ha ganado las elecciones, en alianza con el Partido Socialista, ya instalado en el poder, lo que pone en movimiento una serie de reformas que impactarán profundamente en la vida del protagonista.

La novela fue publicada el 7 de enero del 2015, el mismo día de los atentados en las oficinas de Charlie Hebdo. A las 8.20 AM, mientras Houellebecq (en adelante H.) daba la primer entrevista del día acerca de su nuevo libro, dos individuos irrumpieron armados y mataron a 12 personas, entre las que se encontraba Bernard Maris, economista amigo de H. Por si esto fuera poco, la portada de esa mañana de Charlie Hebdo retrataba precisamente a $\mathrm{H}$. preparándose a celebrar el Ramadán. ${ }^{2}$

En estas circunstancias, parece inevitable leer este libro sin tomar en consideración su contexto. Sin embargo, con ello uno se arriesga a reducirlo al tamaño de la polémica de turno, sin poder rastrear en él los temas que recurrentemente aparecen en la obra de H. De este modo, si bien la novela se inserta en los recientes debates acerca de rol del islam en el futuro de la cultura que dio a luz a la Ilustración, ella se entiende mejor como una continuación de los intereses literarios de H. (como la decadencia de las sociedades occidentales, el individualismo, la disolución de las estructuras sociales, la posibilidad de vivir con sentido, etcétera). En efecto, Sumisión se presta particularmente bien para hacer un análisis general de su obra, pues esta novela posee una estructura bastante simple. Confiesa el propio $\mathrm{H}$ :

\footnotetext{
${ }^{1}$ Barcelona: Anagrama, 2015.

2 Angelique Chrisafis, "Michel Houellebecq: 'Am I Islamophobic? Probably yes", The Guardian, 6 de septiembre, 2015, http://www.theguardian.com/books/2015/ sep/06/michel-houellebecq-submission-am-i-islamophobic-probably-yes.
} 
Pongo en escena a este personaje y progresivamente le quito todo. Empiezo por lo más grave, le quito el amor. Después, y ya es menos importante, le quito a sus padres. Después (...) le quito la posibilidad de creer en Dios. Y para terminar, le quito su relación con Huysmans, que califico como la más antigua de su vida (...) así que a este pobre personaje yo le quito todo, hasta que sólo le queda convertirse. ${ }^{3}$

En efecto, Sumisión mantiene (y muestra de manera bastante conspicua) la estructura narrativa general de las novelas de H. Como veremos, en ellas se somete a los personajes a lo que llamaremos un mecanismo expropiatorio. En este sentido, sus personajes son siempre el mismo, repetido una y otra vez. El autor ha señalado algo similar en entrevistas:

(...) me sorprende un poco oír que hago buenos retratos psicológicos de los individuos, de los personajes: puede que sea verdad; pero, por otra parte, tengo a menudo la impresión de que los individuos son prácticamente idénticos, de lo que llaman su "yo" no existe en realidad, y que en cierto sentido sería más fácil definir un movimiento histórico. ${ }^{4}$

De este modo, es posible entender la obra literaria de H. como la exploración de las distintas estrategias disponibles para intentar eludir el proceso de degradación de la vida, que finalmente deviene en la nada total:

... el universo no es más que una furtiva disposición de partículas elementales. Una figura de transición hacia el caos. Que terminará arrastrándolo consigo. La raza humana desaparecerá. Aparecerán otras razas, que desaparecerán a su vez. Los cielos serán glaciares y estarán vacíos; los atravesará la débil luz de estrellas medio muertas. Que también desaparecerán. Todo desaparecerá. Y los actos humanos son tan libres y están tan desprovistos de sentido común como los libres movimientos de las partículas elementales. ${ }^{5}$

${ }^{3}$ Gonzalo Garcés, "Michel Houellebecq: 'La élite está asesinando a Francia'”, revista Babelia, El País, 23 de abril, 2015, http://cultura.elpais.com/cultura/2015/04/23/babelia/1429802066_046042.html.

${ }^{4}$ Michel Houellebecq, El mundo como supermercado (Barcelona: Anagrama, 2000), 48 .

${ }^{5}$ Michel Houellebecq, H.P. Lovecraft: Contra el mundo, contra la vida (Madrid: Siruela, 2006), 20. 
En este contexto, lo que coloquialmente podríamos llamar felici$d a d$, en el universo narrativo de $\mathrm{H}$. es una excepción, sólo es posible conseguirla en contra el mundo, como parte de una suspensión del mecanismo expropiatorio, un cese de las condiciones normales de la realidad. En este sentido, la pregunta de la novela que comentamos es si acaso "la sumisión" es capaz de lograr la suspensión del mecanismo expropiatorio. Dicho de otro modo, si acaso es verdad que después de que H. termina con François, a este "sólo le queda convertirse". Para responder a esta pregunta es necesario comprender la manera en que este mecanismo opera, cuáles son los presupuestos filosóficos que se ocultan tras este mecanismo.

\section{EMPIEZO POR LO MÁS GRAVE, LE QUITO EL AMOR}

¿Qué es lo que pierde François cuando H. decide quitarle el amor? $\mathrm{Al}$ rememorar su juventud, François reflexiona sobre lo que denomina "el esquema relativamente inmutable" de sus relaciones amorosas:

Nacían al principio del curso universitario a raíz de un seminario, de un intercambio de apuntes, o de una de las múltiples ocasiones de socialización, tan frecuentes en la vida de estudiante, y cuya desaparición consecutiva a la incorporación a la vida profesional sume a la mayoría de los seres humanos en una soledad tan asombrosa como radical. Seguían su curso a lo largo del año, pasando noches en casa del uno o del otro (sobre todo en casa de ella, pues el ambiente tétrico e insalubre de mi habitación se prestaba mal a citas amorosas), llevando a cabo actos sexuales (con una satisfacción que me complace imaginar mutua). La relación acababa después de las vacaciones de verano, es decir, al inicio del nuevo curso universitario, casi siempre por iniciativa de las chicas. Habían vivido algo durante el verano, ésa era la explicación que solían darme, sin precisiones complementarias; algunas, a las que sin duda no les importaba herirme, me precisaban que habían conocido a alguien. Sí, ¿y qué? Yo también era alguien. ${ }^{6}$

Myriam es la última participante de esta serie de relaciones amorosas. Su partida, a causa del ascenso de Mohammed Ben Abbes, líder

\footnotetext{
${ }^{6}$ Houellebecq, Sumisión, 18.
} 
político del partido musulmán que llega al poder (ella es de ascendencia judía, por lo que se marcha a Israel junto a sus padres), marca el inicio del mecanismo expropiatorio al interior de la novela. Una vez privado del placer, François adquiere plena conciencia de la precariedad de su vínculo con el mundo:

Mi cuerpo era la sede de diversas afecciones dolorosas - migrañas, enfermedades de la piel, dolor de muelas, hemorroidesque se sucedían sin interrupción, sin dejarme prácticamente nunca en paz, iy sólo tenía cuarenta y cuatro años! ¿Cómo sería cuando tuviera cincuenta, sesenta o más...? Entonces no sería más que una yuxtaposición de órganos en lenta descomposición, y mi vida se convertiría en una incesante tortura, monótona y sin alegría, mezquina. Mi polla era en el fondo el único de mis órganos que nunca se había manifestado a mi conciencia a través del dolor sino del placer. Modesta pero robusta, siempre me había servido fielmente, o quizá por el contrario era yo quien estaba a su servicio, la idea podía sostenerse, pero en tal caso su férula era muy dulce: nunca me daba órdenes, a veces me incitaba, humildemente, sin acrimonia y sin cólera, a inmiscuirme más en la vida social. Sabía que esa noche intercedería a favor de Myriam, siempre había tenido buena relación con Myriam, Myriam siempre la había tratado con afecto y respeto, y eso me dio un placer enorme. $\mathrm{Y}$ en general, no tenía muchas fuentes de placer; en el fondo ya sólo tenía ésa. Mi interés por la vida intelectual había disminuido mucho; mi existencia social no era mucho más satisfactoria que mi existencia corporal, también se presentaba como una sucesión de pequeños problemas - lavabo embozado, internet averiado, pérdida de puntos del carnet de conducir, mujer de la limpieza deshonesta, error en la declaración de la renta- que también se sucedían sin interrupción, sin dejarme prácticamente nunca en paz. ${ }^{7}$

Privado del placer, la relación de François con el mundo queda reducida a la degradación física, el dolor y el mantenimiento de las condiciones materiales y administrativas de la existencia (ganar dinero, pagar impuestos, hacer las compras, alimentarse, etcétera). Esta expropiación

${ }^{7}$ Ibídem, 95. 
presupone un vínculo específico entre amor y sexualidad. En palabras de François, "el amor en el hombre no es más que agradecimiento por el placer que se le ha dado". ${ }^{8}$ De este modo, a medida que se pierde la posibilidad de experimentar placer, se pierde la posibilidad de amar. Por otra parte, el acceso al placer está mediado por el estatus que los individuos poseen en la sociedad:

Las sociedades animales y humanas establecen diversos sistemas de diferenciación jerárquica, que pueden basarse en el nacimiento (sistema aristocrático), la fortuna, la belleza, la fuerza física, la inteligencia, el talento..., por otra parte, todos estos criterios me parecen igualmente despreciables, y los rechazo; la única superioridad que reconozco es la bondad. Actualmente nos movemos en un sistema de dos dimensiones: la atracción erótica y el dinero. ${ }^{9}$

De este modo se explica la manera en que opera el mecanismo expropiatorio: a medida que envejecen, los individuos pierden sus posibilidades de acceso al placer y, en consecuencia, al amor. En este sentido, el destino que espera a François no es muy distinto al que Daniel vaticina para sí en La posibilidad de una isla:

...llevando una vida ociosa y exenta de preocupaciones, parcialmente ocupada por estudios poco absorbentes, los jóvenes podían dedicarse sin límites a la libre exultación de sus cuerpos. Podían jugar, bailar, amar, multiplicar los placeres. Podían salir de madrugada de una fiesta, en compañía de las parejas sexuales que se hubieran buscado, para contemplar la tétrica fila de empleados que acudían al trabajo. Eran la sal de la tierra, y todo les era dado, todo les estaba permitido, todo les resultaba posible. Más adelante, cuando fundaran una familia, cuando entraran en el mundo de los adultos, conocerían las preocupaciones, el trabajo duro, las responsabilidades, las dificultades de la existencia; tendrían que pagar impuestos, someterse a trámites administrativos sin dejar de presenciar, avergonzados e impotentes, el deterioro irremediable, lento al principio, y después cada vez más rápido, de su propio cuerpo (...). De esa vida dolorosa, marcada por la vergüenza,

\footnotetext{
${ }^{8}$ Houellebecq, Sumisión, 36.

${ }^{9}$ Houellebecq, El mundo como supermercado, 43.
} 
quedaría despiadadamente desterrada toda felicidad. En cuanto quisieran acercarse al cuerpo de los jóvenes, serían perseguidos, rechazados, condenados al ridículo, al oprobio; y en nuestros días, cada vez con más frecuencia, a la cárcel. El cuerpo físico de los jóvenes, único bien deseable que el mundo ha sido capaz de producir, estaba reservado al uso exclusivo de los jóvenes, y el destino de los viejos consistía en trabajar y sufrir. ${ }^{10}$

\section{DESPUÉS, Y YA ES MENOS IMPORTANTE, LE QUITO A SUS PADRES}

¿Cuál es la importancia de esta segunda expropiación? ¿Por qué es importante para François (para H.) la muerte de sus (los) padres? La respuesta no puede provenir de la "cercanía" emocional. En las novelas de H., la relación entre los personajes y sus padres en el mejor de los casos es de indiferencia (cuando no de aversión):

Mi madre se deprimía en Nevers, y no tenía más compañía que su bulldog francés. Hacía unos diez años que no tenía muchas noticias suyas. Aquellos dos frutos del baby boom siempre habían hecho gala de un implacable egoísmo y nada me hacía suponer que fueran a acogerme con benevolencia. A veces me venía a la mente si volvería a ver a mis padres antes de su muerte, pero la respuesta siempre era negativa, y no creía siquiera que una guerra pudiera arreglar las cosas, encontrarían un pretexto para no alojarme; respecto a esa cuestión, nunca les habían faltado pretextos. ${ }^{11}$

Acá tenemos un buen ejemplo de por qué no es posible reducir el análisis de la obra de $\mathrm{H}$. a su biografía. Conocida es la polémica relación entre $\mathrm{H}$. y su madre, quien, luego de enterarse del retrato que $\mathrm{H}$. había hecho de ella en Las partículas elementales, contraatacó con sus "memorias", donde trata a su hijo como un pequeño bastardo malvado, un estúpido y mentiroso arribista, capaz de hacer cualquier cosa por

${ }^{10}$ Michel Houellebecq, La posibilidad de una isla (Barcelona: Alfaguara, 2005), 356.

${ }^{11}$ Houellebecq, Sumisión, 63. 
dinero. ${ }^{12}$ Sin embargo, en esta novela, la relación entre François y sus padres es más compleja.

François se entera de la muerte de sus padres justo después de adquirir conciencia de cómo su vida se va reduciendo a su dimensión material. En este sentido, la pérdida de sus padres posee un carácter simbólico. Ambos fallecimientos marcan momentos clave para la evolución del personaje. François se entera de la muerte de su madre a su regreso de Rocamadeaur. Allí acostumbraba a ir a la capilla de Notre Dame en donde se sentaba frente a la Virgen Negra, símbolo de la cristiandad, la que corresponde a una de las últimas "mutaciones metafísicas" que ha experimentado la humanidad:

... las mutaciones metafísicas - es decir, las transiciones radicales y globales de la visión del mundo adoptada por la mayoría- son raras en la historia de la humanidad. Como ejemplo, se puede citar la aparición del cristianismo. En cuanto se produce una mutación metafísica, se desarrolla sin encontrar resistencia hasta sus últimas consecuencias. Barre sin ni siquiera prestarles atención los sistemas económicos y políticos, los juicios estéticos, las jerarquías sociales. No hay fuerza humana que pueda interrumpir su curso..., salvo la aparición de una nueva mutación metafísica. ${ }^{13}$

Hoy la cristiandad ha dejado de ser una fuerza en el mundo, quedan sus restos materiales, pero su dimensión espiritual nos es inaccesible, ya ha sido reemplazada por una nueva mutación metafísica. En una entrevista, H. señala que "[Marx] no se equivocó de diana al escribir que el triunfo de la burguesía ha ahogado los estremecimientos sagrados del éxtasis religioso, del entusiasmo caballeresco y del sentimentalismo barato bajo las aguas heladas del cálculo egoísta". ${ }^{14}$ La cristiandad, ya extinta, ha dejado a Europa huérfana. No es casual entonces que François se entere de la muerte de su madre inmediatamente después

12 Entrevista a Lucie Ceccaldi, "I never left anybody. It was him that left me", The Guardian, 7 de mayo, 2008, http://www.theguardian.com/books/2008/may/07/ fiction.familyandrelationships.

13 Michel Houellebecq, Las partículas elementales (Barcelona: Anagrama, 2015), 3 .

${ }^{14}$ Houellebecq, El mundo como supermercado, 17-18. 
de su última visita a la estatua de la Virgen Negra, "una estatua extraña, testimonio de un universo enteramente desaparecido". ${ }^{15} \mathrm{Al}$ igual que la muerte de la cristiandad, la muerte de la madre de François es un evento que, a pesar de los múltiples recordatorios y cartas de aviso, pasa totalmente desapercibido. Nadie la llora, nadie la vela (así como nadie lloró nunca la muerte de Dios):

Remitida por el ayuntamiento de Nevers, me transmitía su sincero pésame por el fallecimiento de mi madre y me informaba que el cuerpo había sido trasladado al Instituto Médico Legal de la ciudad, con el que debía ponerme en contacto para tomar las disposiciones necesarias; la carta estaba fechada el martes 31 de mayo. Hojeé rápidamente la pila: hubo una carta de recordatorio el 14 de junio, otra el 28. Finalmente, el 11 de julio, el ayuntamiento de Nevers me informó que, conforme al artículo L 2223-27 del Código General de Colectividades Territoriales, el municipio se había hecho cargo de la inhumación de mi madre en la fosa común del cementerio de la ciudad. Disponía de un plazo de cinco años para ordenar la exhumación del cuerpo para darle una sepultura personal; transcurrido ese plazo, sería incinerado y las cenizas esparcidas en un jardín de la memoria. En caso de que solicitara esa exhumación, me correspondería hacerme cargo de los gastos asumidos por el ayuntamiento: un coche fúnebre, cuatro porteadores y los gastos de sepultura propiamente dichos. No me imaginaba a mi madre llevando una vida social intensa, asistiendo a conferencias sobre las civilizaciones precolombinas o visitando las iglesias románicas del Nivernais en compañía de otras mujeres de su edad; pero en ningún caso me esperaba una soledad tan absoluta. Probablemente también se habrían puesto en contacto con mi padre, y no debió de responder a sus cartas. Era embarazoso pensar que había sido inhumada como una indigente en la hoyanca (como descubrí mediante una búsqueda en internet, así se denominaba coloquialmente a la fosa común), y me pregunté qué habría sido de su bulldog francés (¿sociedad protectora de animales, eutanasia directa?). ${ }^{16}$

François se entera de la muerte de su padre después de un episodio similar. Dado que, a causa del cambio de régimen, ya no puede dictar su

${ }^{15}$ Houellebecq, Sumisión, 155.
${ }^{16}$ Ibídem, 158. 
cátedra en la universidad (sólo hombres musulmanes están autorizados a hacerlo), el "suministro de alumnas" que mantenía "el esquema relativamente inmutable" de su vida amorosa se ve interrumpido. En consecuencia, François se vuelca al mercado de las escorts. Por supuesto, esta estrategia no obtiene resultado alguno, el placer ya le ha sido vedado. Si bien las escorts "eran buenas", no eran tan buenas como para "que me apeteciera volver a verlas, ni para iniciar con ellas relaciones continuadas: ni para darme ganas de vivir. ¿Debía entonces morir? Me pareció una decisión prematura. Fue mi padre quien murió, unas semanas más tarde". ${ }^{17}$

Con ocasión de la muerte de su padre, François se entera de la transformación que éste había experimentado al final de su vida. Mientras que durante la primera mitad de su vida adulta había sido un hombre de negocios burgués perfectamente normal, en sus últimos años se había comprado un refugio en el campo en donde se dedicaba a cazar con sus amigos y disfrutar de su vida con su segunda esposa. "En resumidas cuentas era un hombre que había vivido dos vidas, claramente separadas, y sin el menor punto de contacto", dice François. ${ }^{18}$ La posibilidad de una segunda vida, "claramente separada y sin ningún punto de contacto" con la anterior es lo que se le ofrecerá a François al final de la novela. Pero antes, debe operar totalmente el mecanismo expropiatorio.

\section{DESPUÉS, LE QUITO LA POSIBILIDAD DE CREER EN DIOS}

Luego de que Myriam lo abandona oficialmente, el placer vuelve a la vida de François, fugazmente y por última vez, de la mano de Luisa y Rachida, unas escorts que comienza a frecuentar para suplir la escasez de estudiantes y el exceso de dinero (la universidad le ha dado una generosa pensión al despedirlo por no ser musulmán). Paralelamente, el gobierno de Mohammed Ben Abbes se instala exitosamente y una nueva normalidad comienza a regir. Así como el fervor de la novedad en el ámbito político da paso a un ambiente general de tranquilidad, la fugaz aparición del placer deja a François en un estado aún más precario que el anterior:

\footnotetext{
${ }^{17}$ Houellebecq, Sumisión, 177.

${ }^{18}$ Ibídem, 181.
} 
El milagro de mi primera visita a Rachida y Luisa no se había reproducido, y mi polla se había vuelto de nuevo un órgano tan eficaz como insensible; abandoné el estudio de ellas en un estado que rayaba la desesperación, consciente de que probablemente no volvería a verlas y de que las posibilidades vivas se me escabullían entre los dedos con creciente rapidez, dejándome, como diría Huysmans, "indolente y seco". 19

En este escenario, François contempla el suicidio. Después de una "llorera imprevista, interminable", François decide ir a la abadía de Ligugué, donde Huysmans recibió el oblato. Sin embargo, esta estrategia está destinada al fracaso, pues, como ya vimos, no hay manera de que podamos acceder a la dimensión espiritual del cristianismo, es una mutación metafísica que ya ha sido superada:

A lo largo de los dos días siguientes me acostumbré a la letanía de los oficios, sin lograr empero que me gustara. La misa era el único elemento reconocible, el único punto de contacto con la devoción tal como se entiende en el mundo exterior. Por lo demás, se trataba de la lectura y del canto de los salmos apropiados al momento del día, a veces intercalados con breves lecturas de textos sagrados, efectuadas por uno de los monjes, unas lecturas que también acompañaban las comidas, ingeridas en silencio. La iglesia moderna, construida en los terrenos del monasterio, era de una sobria fealdad y recordaba un poco, por su arquitectura, el centro comercial Super-Passy de la rue de l'Annonciation, y sus vitrales, simples manchas abstractas y coloreadas, no merecían mucha atención; pero todo eso no tenía mayor importancia a mis ojos: no era un esteta, infinitamente menos que Huysmans, y la uniforme fealdad del arte religioso contemporáneo me dejaba casi indiferente. Las voces de los monjes se elevaban puras, humildes y benignas en el aire gélido; estaban llenas de dulzura, esperanza y expectativa. El señor Jesús tenía que regresar, pronto regresaría, y el calor de su presencia ya colmaba de alegría sus almas, ése era en el fondo el único tema de aquellos cánticos, cantos de espera orgánica y dulce. Nietzsche dio en el clavo, con su olfato de viejo cabrón: el cristianismo era en el fondo una religión femenina. ${ }^{20}$

\footnotetext{
${ }^{19}$ Ibídem, 194.

${ }^{20}$ Ibídem, 206.
} 
Luego de este intento fallido, François regresa a París, donde se le ofrece una alternativa: editar las obras completas de Huysmans para la prestigiosa colección Pléiade o reintegrarse a La Sorbona bajo la condición de convertirse al islam. La segunda opción le es ofrecida por Robert Rediger, un ex conservador convertido al islam, flamante nuevo rector de la universidad. Rediger vive en una antigua mansión en la Place Monge (donde vivió Jean Paulhan, editor de La Nouvelle Revue Française), tiene dos esposas, una mayor, afable y experimentada, destinada a las tareas del hogar, y una quinceañera "para otras cosas". En uno de los pasajes más extensos de toda la novela, Rediger, mientras intenta convencer a François de que se convierta al islam y se reintegre a la universidad, le ofrece su visión de la decadencia de Europa:

Los fascismos siempre me han parecido una tentativa espectral, de pesadilla y falsa de devolver a la vida a naciones muertas; sin la cristiandad, las naciones europeas no eran más que cuerpos sin alma, unos zombis. La cuestión era la siguiente: ¿podía revivir la cristiandad? Lo creí, lo creí unos años, con crecientes dudas, cada vez estaba más influido por el pensamiento de Toynbee, por su idea de que las civilizaciones no mueren asesinadas, sino que se suicidan. Y luego todo se desmoronó, en un día: exactamente, el 30 de marzo de 2013; recuerdo que era el fin de semana de Pascua. En esa época vivía en Bruselas, y de vez en cuando iba a tomar una copa al bar del Métropole. Siempre me ha gustado el estilo Art Nouveau: hay cosas magníficas en Praga o en Viena, también hay algunos edificios interesantes en París o en Londres, pero para mí, con razón o sin ella, la cumbre de la decoración Art Nouveau era el Hotel Métropole de Bruselas, y en particular su bar. La mañana del 30 de marzo pasé por delante por casualidad y vi un cartel que indicaba que el bar del Métropole cerraría definitivamente sus puertas esa misma noche. Me quedé estupefacto: me dirigí a los camareros. Lo confirmaron; desconocían las razones exactas del cierre. Pensar que hasta entonces se podían pedir bocadillos y cervezas, chocolates vieneses y pasteles de crema en esa obra maestra absoluta del arte decorativo, que uno podía vivir su vida cotidiana rodeado de belleza, y que todo eso iba a desaparecer, de golpe, ¡en pleno corazón de la capital de Europa...! Sí, en ese momento lo comprendí: Europa ya se había suicidado. ${ }^{21}$

${ }^{21}$ Houellebecq, Sumisión, 240. 
La tesis del suicidio de la civilización ha sido discutida en el contexto francés (véase el horrendo best seller de Eric Zemmour, Le suicide français). ${ }^{22}$ En efecto, $\mathrm{H}$. ha expresado en entrevistas su opinión respecto de la decadencia de Europa, de la inviabilidad del proyecto de la modernidad y de la necesidad de una religión para la existencia de una civilización:

En general, me parece poco verosímil que una civilización pueda subsistir mucho tiempo sin ninguna religión (precisando que una religión puede ser atea, como el budismo). La conciliación razonada de los egoísmos, error del siglo de las luces al que los liberales, en su incurable necedad (a menos que se trate de cinismo, que al fin y al cabo vendría a ser lo mismo), siguen haciendo referencia, me parece una base de una fragilidad ridícula. En la entrevista que usted mencionaba, yo decía ser "comunista, pero no marxista"; el error del marxismo fue pensar que bastaba con cambiar las estructuras económicas, y que el resto vendría por sí mismo. Como hemos visto, el resto no ha venido. Por ejemplo, si los jóvenes rusos se han adaptado con tanta rapidez al ambiente repugnante del capitalismo mafioso es porque el régimen precedente fue incapaz de promover el altruismo. Y no lo consiguió porque el materialismo dialéctico, basado en las mismas premisas filosóficas erróneas que el liberalismo, es por principio incapaz de conducir a una moral altruista. Dicho esto, y aunque soy dolorosamente consciente de la necesidad de una dimensión religiosa, me declaro fundamentalmente no religioso. El problema es que ninguna religión actual es compatible con el estado actual general del conocimiento; está claro que lo que nos hace falta es una nueva ontología. Tal vez estos problemas parezcan exageradamente intelectuales; no obstante creo que tienen, poco a poco, enormes consecuencias concretas. En mi opinión, si no ocurre algo en este terreno, la civilización occidental no tiene ninguna posibilidad. ${ }^{23}$

${ }^{22}$ Para una reseña de este libro, véase Graham Robb, "Is France now the sick man of Europe? It is if it's taking Eric Zemmour seriously", The Spectator, 22 de noviembre, 2014, http://www.spectator.co.uk/2014/11/is-france-now-the-sick-manof-europe-it-is-if-its-taking-eric-zemmour-seriously/.

${ }^{23}$ Houellebecq, El mundo como supermercado, 119-120. 
En la misma línea que $H$. vincula la decadencia europea con la pérdida del cristianismo, Rediger propone el islam como salida a la decadencia occidental:

—Es la sumisión — dijo en voz queda Rediger-. La idea asombrosa y simple, jamás expresada hasta entonces con esa fuerza, de que la cumbre de la felicidad humana reside en la sumisión más absoluta. Es una idea que no me atrevería a exponer ante mis correligionarios, que quizá la juzgarían blasfema, pero para mí hay una relación entre la absoluta sumisión de la mujer al hombre, tal como la describe Historia de $O$, y la sumisión del hombre a Dios, tal como la entiende el islam. Mire - prosiguió-, el islam acepta el mundo, y lo acepta en su integralidad, acepta el mundo tal cual, para hablar como Nietzsche. El punto de vista del budismo es que el mundo es dukkha: inadecuación, sufrimiento. El cristianismo por su parte manifiesta serias reservas: ¿acaso no se califica a Satán de "príncipe del mundo"? Para el islam, en cambio, la creación divina es perfecta, es una obra maestra absoluta. ¿Qué es en el fondo el Corán sino un inmenso poema místico de alabanza? De alabanza al Creador y de sumisión a sus leyes. $^{24}$

Sin perjuicio de haber similitudes en las premisas entre el diagnóstico de Rediger y de H., no podemos adscribir a este último las reflexiones del primero. En efecto, como veremos, la posición de H. respecto del rol que la religión cumple en la cultura occidental es mucho más compleja que la de su personaje, como es posible apreciar en lo que sigue de la novela. El episodio con Rediger deja a François bastante alterado, pues por primera vez contempla la idea de la existencia de Dios, de un ser omnisciente que vigile todos sus actos. Sin embargo, esa noción es incapaz de traerle consuelo alguno; al contrario, lo sume en una desesperación aún más profunda:

... mi primera reacción fue muy clara: era, simplemente, miedo. Poco a poco me calmé, con la ayuda del alcohol, repitiéndome que era un individuo relativamente insignificante, que seguro que el Creador tenía cosas mejores que hacer, etc., pero a pesar de

${ }^{24}$ Houellebecq, Sumisión, 245. 
todo persistía la idea, aterradora, de que de golpe se percataría de mi existencia, descargaría su puño y yo sufriría, por ejemplo, un cáncer de mandíbula, como Huysmans, era un cáncer frecuente entre los fumadores, Freud también tuvo uno, sí, un cáncer de mandíbula parecía verosímil. ¿Cómo me las apañaría, después de una ablación de la mandíbula? ¿Cómo podría salir a la calle, ir al supermercado, hacer la compra, soportar las miradas de compasión y de asco? Y si ya no podía hacer la compra, ¿quién la haría por mí? La noche iba a ser aún larga, y me sentía dramáticamente solo. ¿Tendría al menos el elemental valor del suicidio? Ni siquiera tenía esa certeza. ${ }^{25}$

Después de este episodio François comienza a evaluar seriamente la idea de convertirse al islam. Sin embargo, es necesario preguntarse qué clase de esperanza puede hallar en ello alguien a quien la idea de la existencia de Dios sólo le puede provocar miedo. Antes de responder esta pregunta, es necesario dar una pequeña vuelta para referirse a la última expropiación, puesto que, sin ésta, la conversión no es posible. François debe romper — tal como su padre - todo vínculo con su vida anterior. Es esta necesidad lo que mueve la novela a la última fase de la expropiación.

\section{Y PARA TERMINAR, LE QUITO SU RELACIÓN CON HUYSMANS, QUE CALIFICO COMO LA MÁS ANTIGUA DE SU VIDA}

Como señala H. en su descripción de la trama de Sumisión, la última cosa que pierde François es su relación con Huysmans, la más antigua de su vida. Para comprender esta última expropiación, es necesario detenerse en la manera en que $\mathrm{H}$. entiende la literatura y su relación con la condición humana. En Sumisión (al igual que en múltiples entrevistas), H. ha caracterizado a la literatura como una especie de "último bastión" del pensamiento occidental. En efecto, para él la literatura es lo que nos constituye como individuos:

... sólo la literatura puede proporcionar esa sensación de contacto con otra mente humana, con la integralidad de esa mente, con sus debilidades y sus grandezas, sus limitaciones, sus miserias, sus obse-

${ }^{25}$ Ibídem, 247. 
siones, sus creencias: con todo cuanto la emociona, interesa, excita o repugna. Sólo la literatura permite entrar en contacto con el espíritu de un muerto, de manera más directa, más completa y más profunda que lo haría la conversación con un amigo, pues por profunda, por duradera que sea una amistad, uno nunca se entrega en una conversación tan completamente como lo hace frente a una hoja en blanco, dirigiéndose a un destinatario desconocido. ${ }^{26}$

Esta idea de la literatura como una relación entre individuos es lo que explica la importancia que tiene para $\mathrm{H}$. En efecto, cortar con ella no sólo implica escindirse completamente del resto de la humanidad, sino que también renunciar a toda forma de resistencia y de autonomía, pues es en la novela donde la idea de sujeto, ente autónomo, dueño de su historia, se manifiesta. Para H., el acto de leer un libro es en sí una afirmación de la individualidad:

Al contrario que la música, que la pintura, incluso que el cine, la literatura puede absorber y digerir cantidades ilimitadas de burla y de humor. Los peligros que actualmente la amenazan no tienen nada que ver con los que han amenazado y a veces destruido a las demás artes; están mucho más relacionados con la aceleración de las percepciones y de las sensaciones que caracteriza a la lógica del hipermercado. Porque un libro sólo puede apreciarse despacio; implica una reflexión (no en el sentido de esfuerzo intelectual, sino sobre todo en el de vuelta atrás); no hay lectura sin parada, sin movimiento inverso, sin relectura. Algo imposible e incluso absurdo en un mundo donde todo evoluciona, todo fluctúa; donde nada tiene validez permanente: ni las reglas, ni las cosas, ni los seres. La literatura se opone con todas sus fuerzas (que eran grandes) a la noción de actualidad permanente, de presente continuo. Los libros piden lectores; pero estos lectores deben tener una existencia individual y estable: no pueden ser meros consumidores, meros fantasmas; deben ser también, de alguna manera, sujetos. ${ }^{27}$

De este modo, renunciar a ser un lector es la entrega final: la sumisión. Es la renuncia a ser un sujeto. François es un profesor de lite-

\footnotetext{
${ }^{26}$ Houellebecq, Sumisión, 13.

${ }^{27}$ Houellebecq, El mundo como supermercado, 75.
} 
ratura, ha sido un lector toda su vida. Esa actividad es lo único capaz de definirlo, de darle una identidad distinta a la de cualquier otro ser humano de un país desarrollado del siglo XXI. ¿Qué es François si no es un lector de Huysmans? Es sólo un cuerpo en degradación, la suma de sus dolencias físicas, una cuenta bancaria, un número en el sistema de seguridad social. En tanto lector, todavía podía resistir al mundo desde su relación con Huysmans. Todavía podía, contra todo indicio, ser un sujeto. Esta idea de la literatura como resistencia nos entrega una clave para entender la obra de H. Para él, lo que hace que el conjunto de sus escritos pueda ser considerado como una Obra, así, con mayúscula, es:

la intuición de que el universo se basa en la separación, el sufrimiento y el mal; la decisión de describir este estado de cosas y, quizás, de superarlo. Los medios - literarios o no- son secundarios. El acto inicial es el rechazo radical del mundo tal como es; también la adhesión a las nociones de bien y mal. La voluntad de profundizar en estas nociones, de delimitar su dominio, incluso en mi interior. Después viene la literatura. El estilo puede variar; es una cuestión de ritmo interno, de estado personal. No me preocupan mucho los problemas de coherencia; suele venir por sí misma. ${ }^{28}$

La literatura, entonces, es uno de los medios posibles para expresar el rechazo radical del mundo tal como es. Exactamente lo opuesto a la idea de Sumisión, que es lo que H. busca rechazar:

... la idea de sumisión en la novela podría cambiarse por la de aceptación. El islam acepta el mundo tal como es, con su parte de injusticia. Esa sumisión es peor que la sumisión que exige el capitalismo. Es el fin del mundo. Representa su extinción. Y no tiene nada que ver con el cristianismo, que considera el mundo una creación imperfecta, algo que puede mejorar. ${ }^{29}$

El desafío para $\mathrm{H}$. supone resistir el mundo al mismo tiempo que uno permanece en él. El problema es que, para H., los presupuestos fi-

\footnotetext{
${ }^{28}$ Ibídem, 41.

${ }^{29}$ Laura Fernández, "Michel Houellebecq: 'La sumisión podría suponer la extinción del mundo"”, revista El Cultural, El Mundo, 28 de abril, 2015, http://www. elcultural.com/noticias/letras/Michel-Houellebecq-La-sumision-podria-suponer-laextincion-del-mundo/7724.
} 
losóficos de nuestra cultura hacen que esta resistencia sea cada vez más rara e improbable. Así, una manera de entender la obra de H. es mirarla como un esfuerzo por develar estos presupuestos. Ellos, veremos, están en una relación muy cercana con los espacios que definen el mecanismo expropiatorio de sus novelas. Comencemos por la descripción que $\mathrm{H}$. realiza de la cultura occidental:

Teniendo en cuenta el sistema socioeconómico actual, teniendo en cuenta, sobre todo, nuestros presupuestos filosóficos, es evidente que el ser humano se precipita a corto plazo y en condiciones terribles hacia una catástrofe. De hecho, ya la tenemos encima. Las consecuencias lógicas del individualismo son el crimen y la desdicha. Llama la atención el entusiasmo que nos anima a perdernos; es de lo más curioso. Por ejemplo, sorprende ver la alegre despreocupación con la que se acaba de desbancar el psicoanálisis para sustituirlo por una lectura reduccionista del ser humano basada en neuronas y neurotransmisores. La disolución progresiva, en el curso de los siglos, de las estructuras sociales y familiares; la tendencia creciente de los individuos a considerarse partículas aisladas, sometidas a la ley de los choques, compuestos provisionales de partículas más pequeñas..., todo eso impide que se pueda aplicar ninguna solución política. Así que es legítimo empezar por desmontar las fuentes de huero optimismo. Si volvemos a un análisis más filosófico de las cosas, nos damos cuenta de que la situación es todavía más rara de lo que creíamos. Vamos hacia el desastre, guiados por una imagen falsa del mundo; y nadie lo sabe. Ni siquiera los neuroquímicos parecen darse cuenta de que su disciplina se mueve sobre un campo minado. Antes o después abordarán las bases moleculares de la conciencia; y entonces se darán de bruces con los modos de pensamiento derivados de la física cuántica. No nos libraremos de una redefinición de las condiciones del conocimiento, de la noción misma de realidad; tendríamos que tomar conciencia de todo esto, a nivel afectivo, desde este mismo momento. En cualquier caso, mientras insistamos en una visión mecanicista e individualista del mundo, seguiremos muriendo. No me parece sensato empeñarse durante más tiempo en el sufrimiento y en el mal. Hace cinco siglos que la idea del yo domina al mundo; ya es hora de tomar otro camino. ${ }^{30}$

${ }^{30}$ Houellebecq, El mundo como supermercado, 48-49. 
H. denuncia una "visión mecanicista e individualista del mundo", que se manifiesta en lo que llama "los presupuestos filosóficos" de nuestra cultura. Al mismo tiempo, esta "idea del yo que domina al mundo" también se manifiesta en nuestro sistema socioeconómico. Toma como ejemplos de este fenómeno la reducción de la psiquis humana a la interacción entre partículas (el reemplazo del psicoanálisis por la neurociencia) ${ }^{31}$ y la disolución progresiva de las viejas estructuras sociales bajo los influjos de las fuerzas del capitalismo moderno. Es precisamente este proceso de reducción el que sirve de escenario a las expropiaciones que experimenta François. En efecto, la búsqueda individual del placer vuelve improbables las condiciones en las que puede existir ese fenómeno cultural que llamamos "amor" y que - de acuerdo con H. - es cada vez menos frecuente en nuestros tiempos. Al mismo tiempo, las poderosas fuerzas económicas del capitalismo han reducido al núcleo familiar a su mínimo funcional. Esas mismas fuerzas económicas y esos mismos presupuestos filosóficos, cuyos orígenes se remontan a la Ilustración y a la Revolución Industrial, ${ }^{32}$ son los que llevaron a su fin al mundo que albergó al cristianismo y que, en general, excluyen la posibilidad de la religión. Así, esta "visión mecanicista e individualista del mundo" condena a los individuos y les impide vivir una vida propiamente humana, que trascienda su dimensión material. Así, H. parece creer que una civilización no puede sobrevivir mucho tiempo sin una religión. Sin embargo, la solución no puede ser el islam, pues éste involucra una sumisión "peor que la sumisión que exige el capitalismo". Este último punto nos da la clave para entender uno de los aspectos más crípticos de la novela: su final.

En estricto rigor, la novela termina con François caminando por París, "sin pensar verdaderamente, en cierta forma soñando despierto". Durante esta ensoñación "empezaba a adquirir consciencia $-\mathrm{y}$ eso era una verdadera novedad - de que, probablemente, habría otra cosa". Esa "otra cosa", es su conversión al islam. Todos los eventos que se describen con posterioridad a este pasaje ocurren en la imaginación de François y su significado es explícito:

\footnotetext{
${ }^{31}$ Ver, Scott Stossel, My Age of Anxiety (Nueva York: Random House, 2014).

32 Ver Eric Hobsbawm. Age of Revolution: 1789-1848 (Londres: Hachette UK, 2010).
} 
De madrugada me abrirían expresamente el hamam, cerrado por lo general a los hombres; vestido con un albornoz, recorrería largos pasillos de columnatas coronadas con arcos, de paredes decoradas con mosaicos de extremada delicadeza; luego, en una sala más pequeña, también decorada con refinados mosaicos, bañada por una luz azulada, dejaría correr el agua largamente, muy largamente, sobre mi cuerpo, hasta que mi cuerpo estuviera purificado. Luego me vestiría, habría previsto ropa nueva; acto seguido entraría en la gran sala, dedicada al culto. A mi alrededor se haría el silencio. Me vendrían a la mente imágenes de constelaciones, de supernovas, de nebulosas espirales; también imágenes de fuentes, de desiertos minerales e inviolados, de grandes bosques casi vírgenes; poco a poco, me dejaría penetrar por la grandeza del orden cósmico. Luego, con voz serena, pronunciaría la fórmula siguiente, que me habría aprendido fonéticamente: "Ašhadu anna lā ilāha illā-llāh wa ašhadu ānna Muhammadan rasūlullāh". Lo que exactamente significaba: "Doy fe de que no hay sino un Dios y Mahoma es su profeta". Y acto seguido se habría acabado; sería, a partir de entonces, musulmán. ${ }^{33}$

En esta fantasía, François piensa que, tal como le había ocurrido a su padre, se le "ofrecería una nueva oportunidad; y sería la oportunidad de una segunda vida, sin mucha relación con la precedente. No extrañaría nada".

Resulta curiosa la elección de $\mathrm{H}$. de representar indirectamente, a través de la imaginación de François, la ceremonia de conversión. A la luz del análisis que hemos hecho, mi intuición es que esta elección responde al hecho de que Sumisión es una radiografía del destino que nos ofrecen los presupuestos filosóficos de nuestra cultura. En este sentido, la pregunta no es tan sólo si François va a tomar esta oportunidad de "una segunda vida", es si acaso el lector lo haría. Si es que, después de que nos han quitado todo, nos queda algún lugar desde el cual resistir al mundo. Desde esta perspectiva, la obra de H. es profundamente moral. Quienes ven en H. a un cínico erran el punto. La intención de H. es dar cuenta de "una carencia monstruosa y general" de nuestras formas de vida:

A lo mejor, en el fondo y sobre todo, yo escribo poemas para hacer hincapié en una carencia monstruosa y general (que se puede

${ }^{33}$ Houellebecq, Sumisión, 279. 
considerar afectiva, social, religiosa, metafísica; y cada una de estas aproximaciones es igualmente cierta). También, quizás, porque la poesía es la única manera de expresar esa carencia en estado puro, en estado original; y de expresar simultáneamente cada uno de sus aspectos complementarios. Y tal vez para dejarnos este mensaje mínimo: "Alguien, a mitad de la década de 1990, sintió agudamente el surgimiento de una carencia monstruosa y general; como no fue capaz de dar cuenta con claridad del fenómeno, nos dejó algunos poemas en testimonio de su incompetencia". 34

En última instancia, la obra de H. nos obliga a preguntarnos si acaso hay algo que nos pueda sacar de las "aguas heladas del cálculo racional", de esa "conciliación razonada de los egoísmos". Si es que, ante la (tentadora) oferta de someterse al mundo, seremos capaces de resistir. Si bien H. no ofrece una respuesta concreta a este problema, su obra es un testimonio de los intentos, salvajes y desesperados, de un individuo por encontrar algo de sentido en el mundo del siglo XXI. De ese modo, constituye una forma de resistencia frente a este mundo, que $\mathrm{H}$. se rehúsa a aceptar tal cual es. EP

${ }^{34}$ Houellebecq, El mundo como supermercado, 58. 